\title{
O'Neill's Diversity of Form and Technique: A Study of His Short Plays
}

\author{
${ }^{1}$ Dr Asadullah Larik, ${ }^{2}$ Dr Zaira Wahab, ${ }^{3}$ Dr Alam Raza, \\ ${ }^{1}$ Professor, Iqra University, ${ }^{2}$ Associate Professor, Iqra University, \\ ${ }^{3}$ Assistant Professor, Iqra University
}

\begin{abstract}
Nineteenth century America produced eminent prose writers and poets such as Hawthorne, Melville, Poe, Whitman, Emerson, Thoreau, and Mark Twain but none of comparable quality in the field of drama. The gap remained until after the First World War, the year 1920, to be exact, with O'Neill's production of "Beyond the Horizon" and the inception of the "Theater Guild" which enabled him to face the challenge by refining the genre which had so far lagged behind in its development and maturity, as well as in form and content.

Appreciating O'Neill's contribution, this study aims is to highlight O'Neill's craft in making drama a distinct literary genre with diversity of both form and technique. A thorough thematic analysis focuses primarily on the different forms and techniques which O'Neill has implicitly or explicitly employed in his short plays from the outset of his career until its end. O'Neill's experimentation in form, including his use of multiple acts and scenes, makes him entirely a different dramatist. He was internationally recognized as a dramatist not because he used one or the other technique in his plays but because he blended all those techniques in his plays in a highly personalized manner.
\end{abstract}

Keywords: O'Neill's Short Plays, Diversity, Form, Technique

Highlights: The study of O'Neill's diversity of form and technique reveals that his stature as a great artist stems from the highly personalized approach he brought to this blend of form and technique.

\section{Introduction}

The nineteenth century's most successful dramatists were Dion. Boucicault (1820-90), BronsonHoward (1842-1908), James A. Herne (1839-1901), and David Belasco (1859-1931). On the other side of the Atlantic Ocean, however, European dramatists were making use of more original techniques in producing drama of quality. Ibsen, Hauptman, Gorky, Materlinck, Strindberg, Wedekind, Kaiser, and Toller were all dramatists who used realistic, naturalistic, deterministic, expressionistic, and symbolistic techniques in their plays.

Twentieth century American drama, therefore, faced the challenge to produce dramatists who could assimilate European dramatic techniques in their writings and yet make them distinctively American. Clyde Fitch's experimentation with realistic techniques, and Professor George Piece Baker's famous English 47 course (the 47 workshop), at Harvard from 1905 to 1925, helped in producing America's greatest dramatist Eugene O'Neill as well as other twentieth century playwrights. Eugene O'Neill faced this challenge by refining the genre which had lagged behind in its developments and maturity, as well as in form and content. O'Neill was conscious of the fact that American drama needed to reach parity with its European counterpart. He, therefore, had to take certain bold measures by infusing a great variety into the genre. It was because of his stature and genius that the genre received recognition not only at home but in Europe as well.

\section{Methodology}

The purpose of this study is to measure the success of O'Neill in making drama a distinct literary genre with diversity of both form and technique.

This study focuses primarily on the different forms and techniques which O'Neill has implicitly or explicitly employed in his short plays from the outset of his career until its end. O'Neill's experimentation in form, including his use of multiple acts and scenes, makes him entirely a different dramatist. The study makes an in-depth thematic analysis of all his short plays. The categories studied include the number of scenes, number of pages, setting, nature of dialogue, time period, characters, asides, masks, monologues, parallels, verbal repetitions, sound effects, music, lighting, and the like and projected reality through poetic form.

The study also highlights O'Neill's treatment of philosophical ideologies such as realism, naturalism, expressionism, stream of consciousness, symbolism, mysticism and psychoanalysis in his short plays. 


\section{The Thematic Analysis}

The form of O'Neill's plays does not reveal the monotony of any one particular tradition. Instead, he offers his audience a great variety of one to four act plays, and even one trilogy Mourning Becomes Electra which totals thirteen acts in all. Other plays such as The Emperor Jones and The Hairy Ape contain eight and eleven scenes respectively. The number of characters in his plays also vary from one (Before Breakfast) and two (Hughie) to around fifty characters (Marco Millions). Furthermore, there is quite a variation in the presentation of scenes within the acts of the play. Only a few plays are well-divided into equal number of scenes; most reveal an irregular division of scenes within the acts. Some acts have only one scene while others in the same play might have two to four scenes each.

Some plays contain prologues and epilogues (Now I Ask You. Marco Millions and The Great God Brown), others contain only epilogues (More Stately Mansions). The settings of the plays also offer the audience great variety. His settings present the land in different forms, the sea in different moods, the forest and jungle from different perspectives. Some plays are as short as ten to twenty pages while others, such as Mourning Becomes Electra and Strange Interlude, are as lengthy as novels. The time period within the acts and scenes of All God's Chillun Got Wings spans over seventeen years and over fifteen years in The Great God Brown.

Conversely, the narratives of quite a few other plays cover only a few days, sometimes less than twenty-four hours. O'Neill's characters span a variety of social and ethnic ranks: sailors, prostitutes, farmers, Negroes, and people of different religions. His language is communicative to a wide audience: he uses a folk idiom and dialects which are commonly understood. His use of spellings and apostrophes is also significant.

O'Neill who always desired "to be an artist or nothing" revised the unhappy ending: "no dramatist was more responsible for the revival of the unhappy ending and the triumphant return of the tragic spirit than Eugene O'Neill, the little theater gift to American drama" (Gagey, 39). Gagey goes on to say that, "in the many critical works about him Eugene O'Neill has been called variously realist, poet, mystic, seer, and plain writer of melodrama. These designations all fit to a certain degree, for regardless of his eventual reputation, O'Neill remains a many sided figure" (Gagey, 39). O'Neill's multidimensional figures exist because of this diversity of form and technique in his plays which gives him an edge over other dramatists of his age. His popularity and international recognition was the result of the articulate manner in which he designed his plays. He presented life's various aspects and themes by adopting different forms and techniques. Bhagwat Goyal (1970) in this connection says: "In his constant search for a suitable dramatic form to enshrine his vision of life, O'Neill experimented with various forms and techniques. But though his experiments seem daringly different from each other, there is an underlying unity of purpose in them.

O'Neill's purpose for using different forms and techniques is to present men in a social order beaten up by the forces of a system which "tortures, thwarts, starves and disillusions him (Winthers, 189). Sophus Winther's study of O'Neill reveals that "in order to understand and appreciate the life force of O'Neill's world it must be remembered that he does not think that death means the negation of living or that the fear of death should destroy the value of life. He says yea to death with the same enthusiasm that he greets life. He does not bow before any aspect of life in humility, for life to him is its own reason for being, and not the servant of supernatural forces" (Winther, 225-226). There is a general consensus that O'Neill accepted life with all its tragic defeat and out of its chaos created a beauty that is good in itself. It is this affirmative value which prevents O’Neill from being branded as a pessimist.

O'Neill's plays are not mere records of private agonies and sufferings as the body of criticism may have suggested. O'Neill achieved his objective as a great artist by looking at man as a being whose life is a tragic, exciting and beautiful adventure. He shows theatrical craftsmanship and emerges as an uncompromising idealist.

Joseph Wood Krutch in his book The American Drama Since 1918 says that, "O'Neill is of Shakespearean proportions." His assessment is based upon the fact that O'Neill produced a great variety in his plays and he could do it only by revolting against existing dramatic conventions. He continues Part of O'Neill's childhood was spent on tour with his father, the romantic actor James O'Neill, who for years went up and down the country performing in the Count of Monte Cristo. Doubtless this fact influenced him in the direction of the theater and doubtless early familiarity with popular drama has had something to do with his revolt against the theatrical convention and his shrewd theatrical sense of how even his most eccentric technical innovations will work out on the stage (Krutch 82).

O'Neill experimented with and used effectively these new techniques in his plays while the whole of Europe was already engaged in experimentation. He felt that drama would be incomplete unless it was unfolded on the stage. Although he tried his hand at realism in some of his earlier and later plays, realism as a mode of dramatic expression proved to him quite inadequate since it could not depict the intensity of inward action nor could it externalize his vision. Hari Mohan Prasad notes O’Neill's shifting from one technique to another: "Like Picasso, O'Neill was shifting in his own lifetime from style to style, partly as a reflection of the shifting characters of the last four decades in Western society, and parody like a man dialing a ship's radio on the ocean 
trying vainly to find the wavelength on which he can talk to his fellow men" (Prasad, 1987). In the words of R.F. Whitman, O'Neill "was always exploring, always hoping to find a medium of communication, that would satisfy his needs both as a dramatist and as a man" (Prasad 7). About the different modes and techniques O’Neill himself affirms:

So I am really longing to explain and try and convince some sympathetic ear that I've tried to make myself a melting pot for all three methods, seeing some virtues for my ends in each of them, and thereby, if there is enough real fire in me, boil down to my own technique (Prasad,1987).

O'Neill's diversity of form and technique was therefore quite obvious as he made use of all available forms and techniques in his plays. He employs asides, masks, monologues, parallels, verbal repetitions, sound effects, music, lighting, and the like and projected reality through poetic form. He uses the techniques of realism, naturalism, expressionism, stream of consciousness, symbolism, mysticism and psychoanalysis. He takes a psychological approach in Beyond the Horizon and Different. He uses romantic naturalism in earlier plays. He uses symbolism, mysticism, expressionism in the famous plays: The Emperor Jones, The Hairy Ape. The Great God Brown. Lazarus Laughed. Dynamo. Desire Under the Elms, for instance, symbolically develops a Greek theme. Strange Interlude follows the stylistic pattern of a stream of consciousness novel. However, Freudian psychology works well in Mourning Becomes Electra and Desire Under the Elms. The Iceman Cometh and Long Day's Journey Into Night stylistically resemble Gorky and Chekhov in their metaphysical naturalism.

The salesman has been a central character of post-war American drama .The Iceman Cometh by Eugene portrays the salesman as a real character. As an audience, we may think he is crass; at the same time the ideology of the salesman has somehow managed to affect all of us. We are all salesmen now, of our work or of our selves - (Bloom Harold. June 2012).

A clear understanding of O'Neill's dramatic process and techniques can be achieved only after a thorough study and analysis of his plays. The attempt here is to study and analyze those selected plays which exhibit the diversity of form and technique used by O'Neill in a highly personalized manner. This study makes a critical analysis of his diversity of form and technique he has employed in his short plays.

"I am no longer interested," he said (The New York Herald Tribune, November 16, 1924), in the one act play. "It is an unsatisfactory form - cannot go for something poetical, for something spiritual in feeling that cannot be carried through a long play" (Clark, 55). Eugene O'Neill wrote around twenty one act plays and four other short plays (two two-act plays and two plays each written in eight scenes.) These short plays were completed between the years 1913 and 1942 which covers both the early period and the periods of "diverse experimentation" and "relative stability" of O'Neill's career as a dramatist. Although the form of the short play may not have completely satisfied O'Neill at certain times, he kept writing in this form until the year 1942.

O'Neill, known for his experimentation, did not concentrate on any single form or technique which could be called O'Neillian. He preferred to introduce a great variety of form and technique into the American drama and thus wrote in different forms by using different techniques. This section of the study will discuss and analyze selected short plays.

Eugene O'Neill was just a novice in the field of drama when he wrote his first one-act play, A Wife for a Life (1913), a work blending melodramatic and realistic techniques. The dialogue between the Older Man, who has abandoned his wife Yvette, and the Younger Jack who loves her, illustrates this:

The Older Man: (jokingly) Then what is the attraction the effete East has to offer? (mockingly) it's a woman I suppose Jeck: (with Dignity) An Angel Rather.

The Older Man: (cynically) they're all angels at first. The only trouble is their angelic attributes lack staying qualities, (then bitterly) At any rate you'd find them hard to prove by my experiences.(Bogard, v. 1, 6)

The Older Man trembles in shock as he hears Jack proposing the toast: ". . . Here's to the Yvette mine!" He blames fate for all this and surrenders by saying: "What tricks fate play with us." (Bogard, V.l, 6) He gives up his wife for his life saved by Jack at the beginning of the play. Toward the end of the play, he softy quotes: Greater love hath no man than this that he giveth up his wife for his friend.

(Bogard, v. 1, 11)

The same combination of melodrama and realism is used in another one act play, The Web (1913), which focuses on Rose, a young 22-year old prostitute who looks much older because of the poverty and sickness which have become a part of her life. O'Neill depicts her in deepest dejection as she cannot afford medicine for her chronically ill child and finds herself constantly threatened by her regular visitor Steve "cadet" to get rid of that child. She begs him not to separate her from the child:

Rose: Please, Steve, for the love of Gawd Lemme keep her!

She's all I got to live for. If yuh take her away I'll die.

I'll kill myself. (Bogard, v. 1, 19)

She gets momentary relief when the fugitive Tim Moran enters to help her but this intrusion only 
aggravates her misery by separating her from her child, her only source of happiness and hope. Tim Moran gives her a roll of bills, and suggests that she take her child to the mountains for its health. Her gratification at Moran's kind gesture is short-lived when he is murdered by Steve who was lurking outside:

Tim: (his eyes glazing) Good kid- mountains - get rid of that cough, (he dies)

Rose: (rushes to Tim and kneels beside him, holding his head to her breast) Tim! Tim! Speak to me, Tim! (she kisses him frantically) (Bogard, v. 1, 26)

Afterward, Rose is implicated in Moran's murder and her daughter is taken from her by the Police:

Rose: Honest to Gawd, I didn't do it. He gave me this money. Someone shot him from the window.

Second Plain Clothes Man: Stop that noise! Whad'yuh take us for-boobs? (Bogard, v.1, 27)

Stretching both arms above her head, Rose cries bitterly and mournfully out of the depths of her desolation: "Gawd! Gawd! Why do yuh hate me so?" (Bogard, v.l, 28). She is tragically caught in that "web" of fate.

Paul Duane Voelker identifies O'Neill's early diverse one-act plays

* as follows:

O'Neill's first work was a one-act entitled A Wife for A Life. In the next several months he wrote five more - The Web, Thirst, Recklessness, Warnings.and Fog. Thirst and Fog were in the expressionistic mode, the rest were realistic) (Hyashi, 107). .

It is quite obvious that O'Neill made use of different techniques right from the start. Frederic Carpenter says:

Not only had he continued to grow, but his individual growth coincided with that of the modern world. From the sentimental self-pity of "the lost generation" to the more astringent pessimism of modern existential philosophy, the world changed, and O'Neill changed with it. (171)

One indication of this change was the shift in setting from city to sea in plays such as Thirst (1913) and Fog (1914). Here O'Neill uses melodramatic, realistic, naturalistic, super- naturalistic, and expressionistic techniques. The one act play Thirst tells the story of three persons dying of thirst. It employs melodrama, realism, naturalism all blended in scenes characterized by O'Neill's personalized artistry. The three characters in the play a dancer, a gentleman, and a sailor - are isolated from the rest of the world, waiting for help to come. They do not see any ships in sight:

The Dancer: My God this is horrible to wait and wait for something that never comes.

The Gentleman: I have hoped for many things in my life. Always I have hoped in vain. (Bogard, v.l, 36)

Their frustration, anger and agitation mount to the accompaniment of the sailor's monotonous song:

The Gentleman: "God! God! What a joke to play on us!"

The Dancer: What have we done that we should suffer so?

The Gentleman: What pitiful creatures we are.

The Gentleman: Besides, what does it matter? Sharks or no sharks - the end is tire same.

The Gentleman: There is nothing - but the sharks - that seems to live.

The Dancer: God! Oh God! Must this be the end of all?

The Gentleman: Is this the end of God? So- I might wait with equal justice. But the blind sky will not answer your appeals of mine. Nor will the cruel sea growmerciful for any prayer of ours - God, if we only had a little water. (Bogard, v.l, 38-42)

The Sailor, silent throughout except for his singing, finally manifests interest in life after the death of the dancer. Indifferent earlier to the dancer's offer of first her necklace, and then herself for water, he now attacks tire gentleman when he throws her dead body into the sea. The scuffle results in the drowning of both toward the end of the play.

The one-act play Fog focuses on three characters: a poet, the symbolic embodiment of idealism; a businessman, the abstract representative of materialism; and a woman with a dead child -all adrift on a lifeboat in dense fog desperately looking for help. The scenes in the play are quite melodramatic:

Second Voice: (after a long pause) So you think the child's death was a terrible thing?

Fust Voice: (in astonishment) Of course! Why? Don't you?

Second Voice: No

First Voice: But you said just a minute ago that --

Second Voice: I was speaking of the grief and despair of the mother But death was kind to the child.

It saved him many a long year of sordid drudgery.

(Bogard, v. 1, 99)

Afterward, when the fog clears, the sailors' boat which is guided by the voice of the child rescues them. The sailors find the woman who was alive, in the meantime has died and they find the child alive who was dead for twenty-four hours. This scene which occurs toward the end of the play presents a blend of super naturalistic 
and expressionistic techniques:

The Poet: (softly) The woman is dead.

The Businessman: Dead! - -

The Officer: Too bad! But the child is alright, of course?

The Poet: The child has been dead for twenty-four hours. He died at dawn yesterday (Bogard, v. 1, 11 2)

Bound East for Cardiff (1914), another short one act sea play, is considered a mature O'Neil] work which anticipates the lengthier play Anna Christie (1920). O'Neill's symbolism in his sea plays is at its best. His usual symbols - sea, fog, ice, and bad cold weather - are present here together with the symbolic figure of Yank who dies complaining about the sea more or less in the same illusionary manner as Chris in the play Anna Christie

Yank: This sailor life ain't much to cry about leavin' -

Just one ship after another, hard work, small pay, and bum grub; and when we git into port, just a drinkendin' up in a fight, and all your money gone, and then ship away again. Never meetin' no nice people; never gittin outa sailortown, hardly in any port; travelin' all over the world and never seein' none of it'; widiout no one to care whether you're alive or dead, (with a bitter smile) There ain't much in all that that'd make yuh sorry to list it, Drisc.

Driscoll: (gloomily) It's a hell uv a life, the sea.

Yank: (musingly) It must be great to stay on dry land all your life and have a farm with a house of your own with cows and pigs and chickens, 'way on the middle of the land where yuh'd never smell the sea or see a ship. It must be great to have a wife, and kids to play with at night after supper when your work was done. It must be great to have a home of your own, Drisc. (Bogard, v.l, 195)

Before Breakfast (1916), another fine example of the short play, uses the dramatic monologue, a technique which O'Neill exploits in many plays during his later years. There is only one speaking character throughout the play. Mrs. Rowland while preparing breakfast talks to her husband, Alfred, a Harvard graduate, son of a millionaire, a poet, and an artist without a job, about their financial difficulties and other domestic problems. She receives no answer from Alfred who is in the toilet next door. She is horrified to find him dead, his throat cut with a razor.

Dreamy Kid (1918), another melodrama tells the story of a dreary youth Abe, a murderer running away from the police. He finds himself secure at the home of his dying grandmother whom he will not leave because he fears her curse. The grandmother feels happy about Abe's prayers toward- the end of the play when the police are outside.

This play focuses upon the traditions and superstitions of Negro characters and anticipates the more popular success The Emperor Jones.

The Rope (1918) is set on a farm and concerns an old farmer Abraham Bentley whose first wife dies because of his brutal behavior and stinginess. He marries another woman famous in the town for her infidelities. Bentley's daughter Annie by his first wife hints that this second wife's son Luke has another father. Bentley's son-in-law Pat Sweany and his son Luke are determined to punish the old man by finding the old man's money. In this play one finds some anticipation of Desire under the Elms.

It would be worthwhile to discuss at this point another short play Hughie written in 1942, long after O'Neill had gained recognition as a world dramatist, including a Nobel Prize and three Pulitzer Prizes. Hughie confirms the diversity of O'Neill's dramatic method during his mature period Hughie is a melodrama that employs the dramatic monologue. The narrator "Erie" Smith, a teller of tales, talks about Hughie who is already dead. He repeats a number of times that "Hughie was one great little guy. Smith tries to establish a comforting relationship with the new night clerk, the only other character in the play, and wants to make him a second Hughie, He was quite comfortable with the dead Hughie because Hughie was a nice little guy on whom he could impose his notions of being an important person, a romantic patron and a gangster. He draws the new clerk's attention when he says:

But Hughie's better off, at that, being dead. He's got all the luck. He needn't worry now. He's out of the racket. I mean, the whole god damned racket. I mean life.

He repeats this statement:

He's gone - like we all gotta go. Him yesterday, me or you tomorrow, and who cares, what's the difference? It's all in the racket, huh?

(Bogard, v. 3, 842-51)

The dramatic monologue technique here indicates a great deal of interior monologue in the character of the night clerk. The techniques of dramatic monologue and interior monologue present the blend of realistic, naturalistic, and expressionistic scenes, and, to a certain degree, elements of absurdity as well. O'Neill's portrayal in this play of a silent universe without God is quite similar to certain scenes in Thirst and Fog.

O'Neill tried his hand at only two two-act plays. The first, Different (1920), whose two acts are 
separated by thirty years, presents characters as psychological cases. The second and more popular All God's Chillun Got. Wings (1923), written in an expressionistic technique, deals with the marriage relationship of a Negro and a white girl. Regarding O'Neill's portrayal of black characters in his plays, Ann Dorris Hunt says:

Eugene O'Neill profoundly changed American drama in many ways. One of the outstanding innovations is his portrayal of black characters in drama as human beings, not just stereotypes (Hyashi, 110).

Eugene O'Neill portrays black characters in at least six of his plays. These characters range in age, in education, and in occupation. In this play also one finds black characters from the illiterate to the highly literate, ranging in age and occupation. Ella Downey, the white girl, is grateful to Jim Harris, the black boy, for defending her as a child and, later, for rescuing her from humiliation among her own kind. While talking to Jim she says about her color: "I hate it I wish I was black like you" (Bogard, v. 2, 281). As a child Ella defends Jim.

When the other white kids such as Shorty call Jim nigger," Ella says that "Jim Harris is the only white man. The only white man in the world! Kind and white. You are all black - black to the heart" (Bogard, v. 2, 291). Jim Harris is ambitious in striving to pass his law examination and makes heroic efforts to overcome what he feels are racial limitations. He marries Ella and they live as a happy couple for a short while, but they are beset by the problems of racial prejudice which create tensions, resentments, and ultimately result in destruction. The first act's four scenes span fifteen years. The three scenes of the second act span three years: it is here that the marriage fails, destroying Jim and Ella. Ella feels isolated within a black family and begins to hate Negroes. We know that Ella's racial prejudice and Jim's lack of self- confidence are due to the oddities of history and superstition. Toward the end of the play, we hear Jim Harris saying to Ella:

Maybe He can forgive what you've done to me; and maybe He can forgive what I've done to you; But I don't see how He's going to forgive Himself. (Bogard, v. 2, 314) Eugene O'Neill's short popularly known expressionistic plays written in eight scenes are The Emperor Jones (1920) and The Hairy Ape (1921). In The Emperor Jones, the first and last scenes are conceived realistically, whereas the central six scenes constitute dramatic monologues of the protagonist Jones. The sound of the drums begins to grow right from the first scene.

Jones loses his self-confidence and regresses to the condition of a primeval savage. He squanders all his treasured bullets, his clothes become rags, and he is destroyed by personal and racial memories as well as subconscious fears. His hat is lost, his face is scratched and he speaks like a man who has lost his senses. Angrily tearing off his coat, he feels tired and miserable and begs for mercy:

What-what is I doin? What is dis place? Seems like I know dat tree-an dem' stones-an'de river I rememberseems like I been heahbefo'(tremblingly) Oh, Lawd, pretect

dis sinner!

(Bogard, v. 1, 1057) invincibility.

Jones is killed by the silver bullet which he always had in his revolver to preserve the legend of his

In The Hairy-Ape, Yank is a personification of brute energy. He is proud of his energy and asserts that it is his energy on which the ship and the passengers ultimately depend. He shows no respect for religion and has no understanding of home. Mildred Douglas, a rich anaemic self-conscious of her superiority, is terrified of Yank and views him as a disgusting beast. Yank, outraged by Mildred's loathing for him, becomes obsessed with the desire to find some class to which "he belongs." In the final scene Yank visits the zoo hoping the gorilla will accept him. Here Yank symbolically is reduced to the -status of a caged and frustrated animal that is ultimately crushed and killed at the end. Yank's monologue in the final scene is both touching and symbolic:

Sure! Dat's de way it hits me, too. On'yyuh're lucky, see? Yuh don't belong wit'em and yuh know it. But me, I belong wit'em-but. I don't see? Dey don't belong wit me, dat's what get me? Tinkin' is hard. (Bogard, v. 2, 162) As Yank is crushed, he says:

He got me, and right. I'm troue. Even him didn't think I belonged.

Then with despair, he cries:

Christ, where do I get off at?

Where do I fit in? (163)

The analysis of O'Neill's short plays reflects his interest in continuous experimentation. He switches from one technique to another and at certain times blends different techniques in a very personalized manner even in the form of writing short length plays.

\section{Conclusion}

O'Neill has indeed emerged as a leading American dramatist and has "outshone" his contemporaries both at home and abroad. He has touched on almost all major modern themes in his plays and dramatized aspects of life in many different ways. Although he is primarily considered a great tragedian, he also wrote comedies and a comic tragedy and he introduced comic elements into several serious plays. He used both traditional and modern techniques to express his point of view regarding life. He uses all kinds of symbols, masks and asides to 
show that he really was an artist. John A. Raleigh comments on O'Neill's versatility:

Each separate play is a kind of wedge driven into this 360 degree circle, or created world. Accordingly, each play is simultaneously a psychological document, a moral document, an historical document, a philosophical document, and so on. No one play can be reduced to one theme or preoccupation or genetic theory; rather each is a microcosm mirroring, in its own way, the macrocosm of the whole. (Raleigh, xv)

Raleigh's assessment emphasizes that O'Neill's greatness does not stem from any single theme, technique, or particular philosophy, but from the great variety he used to create an entirely new dramatic world. Our study of O'Neill's diversity of form and technique also reveals that his stature as a great artist stems from the highly personalized approach he brought to this blend of form and technique.

\section{References}

[1]. Alexander, Doris, (1962) The Tempering of Eugene O’Neill., New York: Hartcourt, Brace and World

[2]. Bloom Harold. (June 2012), The Iceman Cometh: A play in four acts by Eugene O’Neill. New York premiere: Martin Beck Theatre, 9 October 1946, The Iceman Cometh, New Haven, CT: Yale University Press, 2006. Posted on 6 June 2012

[3]. Bogard, Travis,(1988) Eugene 0'Neill: Complete Plays. (3Vols.) New York, Oxford University Press,

[4]. Gagey, Edmond M. (1947), Revolution in American Drama, New York: Columbia University Press

[5]. Goyal, Bhagwat S. (1970), O'Neill and his Plays. New Delhi: Aaartic Book Center Goyal, Bhagwat S. (1975), The Strategy of Survival: Human Significance of O’Neil's Plays. Ghaziabad, India: Vimal Prakasher

[6]. Hayashi, Tetsumaro. (1983), Eugene O'Neill: Research Opportunities and Dissertation Abstracts. Jefferson, North Carolina: McFarland

[7]. Krutch, Joseph Wood. (1957)The American Drama since 1918: An Informal History.New York: Braziller

[8]. Prasad, Hari Mohan (1987).The Dramatic Art of Eugene O’Neill, New Delhi: Associated Publishing House

[9]. Raleigh, John (1966). The Plays of Eugene O’Neill, Carbondale, IL, SIU Press Ronald H. Wainscot (1998), Staging O’Neill: The Experimental Years, A Survey Of The Dramaturgy And Scenography of O’Neill's plays; Yale University Press, Beyond the Horizon and the struggle towards Expressionism, Posted on 10 June 2012

[10]. Winther, Sophus Keith. (1961), Eugene O'Neill: A Critical Study. New York: Russell and Russell

[11]. How we receive O'Neill's early and mid period plays depends a great deal upon how we read them (Wainscot 1998).

[12]. Ronald H. Wainscot's Staging O’Neill: The Experimental Years, 1920-1934(1998), A Survey Of The Dramaturgy And Scenography of O'Neill's plays; Yale University Press, Beyond the Horizon and the struggle towards Expressionism, Posted on 10 June 2012

[13]. The salesman has been a central character of post-war American drama. The Iceman Cometh by Eugene portrays his true plight. As an audience, we may think he is crass; at the same time the ideology of the salesman has somehow managed to affect all of us. We are all salesmen now, of our work or of our selves - (Bloom Harold. June 2012.

[14]. Bloom Harold. June 2012, The Iceman Cometh: A play in four acts by Eugene O’Neill. New York premiere: Martin Beck Theatre, 9 October 1946, The Iceman Cometh, New Haven, CT: Yale University Press, 2006. Posted on 6 June 2012 